\title{
EMBRYONIC DEVELOPMENT OF CLARIAS BATRACHUS UNDER THE INFLUENCE OF AERATION AND WATER FLOW
}

\author{
Sk. Mustafizur Rahman*, Md. Ahasan Habib, Quazi Zahangir Hossain ${ }^{1}$, \\ Md. Noman Siddiqui, Md. Mostafizur Rahman and Md. Nazmul Ahsan \\ Fisheries and Marine Resource Technology Discipline \\ ${ }^{1}$ Environmental Science Discipline \\ Khulna University, Khulna - 9208, Bangladesh \\ *E-mail: mustafizfmrt@yahoo.com
}

\begin{abstract}
Specific investigation on the time (h) required for catfish, Clarias batrachus, embryos to reach various early developmental stages were carried out under different experimental conditions. Five hundred fertilized eggs were incubated in tray $\left(28^{\circ} \mathrm{C}-30.5^{\circ} \mathrm{C}\right)$ with continuous water flow and aeration $\left(T_{1}\right)$, with only continuous water flow $\left(T_{2}\right)$ or aeration $\left(T_{3}\right)$ and without continuous water flow and aeration $\left(\mathrm{T}_{4}\right)$. Fertilized embryos hatched successfully in all treatments except for $\mathrm{T}_{4}$. Time requirements for 2-cell, 4-cell, 8-cell, morula, germinal ring, yolk-plug, twisting movement, prehatching and hatching were comparable for all treatments. However, developmental speed was ceased from yolk-plug stage for $\mathrm{T}_{4}$. Time requirements for two-cell, four-cell, eight-cell, morula, germinal ring, yolk-plug, twisting movement, and hatching were $0.43,0.48,0.53,3.52,6.07,8.50,15.04$, 20.08 , and $21.40 \mathrm{~h}$, respectively for $\mathrm{T}_{1} ; 0.44,0.47,0.51,3.49,6.10,8.51,15.13,20.19$, and $21.56 \mathrm{~h}$, respectively for $\mathrm{T}_{2} ; 0.50,0.53,0.59,3.52,6.13,8.53,15.11,20.18$, and $22.13 \mathrm{~h}$, respectively for $\mathrm{T}_{3}$. Fertilized eggs of $C$. batrachus incubated in tray with only aeration $\left(\mathrm{T}_{3}\right)$ is sufficient for successful hatching and could be cost-effective for hatchery operation.
\end{abstract}

Key words: Clarias batrachus, embryonic development, water flow, aeration, hatching.

\section{INTRODUCTION}

Sustainable and quality seed production from the available brood stock is desirable for any hatchery operation. This is particularly important in the farming of walking catfishes because their wild brood/seed collection is very much limited due to environmental changes, pollution, over fishing and genetic introgression between populations as a result of anthropogenic introductions. Embryonic development and larval development studies provide interesting information that are imperative and consequential to the successful rearing of larvae for large scale seed production (Marimuthu and Haniffa 2007). The observations made after studying fish eggs, embryonic and larval development in fisheries sciences, aquaculture, taxonomy and ecology have been much highlighted (Blaxter 1974).

Walking catfish, Clarias batrachus is a popular and high priced fish in Bangladesh with promising importance for aquaculture. In Bangladesh, it is known as magur falls under the order Siluriformes and family Claridae and found in a wide variety of habitats including lakes and 
rivers but are best known for their ability to thrive where many fishes can not. Warm, stagnant, often hypoxic waters such as muddy ponds, canals, ditches, swamps and flooded prairies are common habitat for this fish. Except for occasional foraye to the surface for gulps of atmospheric air, this species spends most of its time on or near the substrate.

The embryonic and larval stages are considered very sensitive indicators of environmental disturbances (Marimuthu and Haniffa 2007). They are also indispensable in the study on ontogeny and phylogeny of their families (Legendre and Teugels 1991 and Verreth et al. 1992). In addition, such studies on the embryonic or larval development of any culturable species can be useful in directing the husbandry efforts of fish farmer to the specific state and requirements of each larval stage. Embryonic development of $C$. macrocephalus and $C$. batrachus has been described by Mollah and Tan (1982) and Thakur (1980) where fertilized eggs were incubated in trays with continuous water flow system. As described previously, walking catfish can withstand any harsh conditions and breed in stagnant water as well as our preliminary study revealed that this species develop the fertilized eggs in the absence of continuous water flow (Habib et al. 2004). Continuous water flow, in case of mass production, increases the operation cost. Thus, the main purpose of this study is to ascertain the effect of various experimental conditions (e.g., continuous water flow or in stagnant water in the presence/absence of aeration) on the viability of embryos in order to be able to evaluate the effect of alternations of these variables in the hatchery. This study further describes the characteristic features of each embryonic stage of C. batrachus.

\section{MATERIALS AND METHODS}

Brood collection and induced breeding: Mature healthy broods of Clarias batrachus were collected from the local market. Immediately after collection, broods were transferred to the fish physiology and breeding laboratory and kept in the closed aquaria until induced breeding. For this experiment, seven females and three males ranged from 130 to $190 \mathrm{~g}$ for male and 100 to $160 \mathrm{~g}$ for female were used. During stocking in aquaria, broods were not given any supplementary feed from outside. The larvae of $C$. batrachus were obtained by induced breeding method using pituitary gland extracts (PG). Dose administrations of PG were performed according to Hossain et al. (2006).

Experimental conditions: To assay the embryonic development, fertilized eggs were placed in three different experimental conditions, including continuous water flow plus aeration; only continuous water flow, only aeration and stagnant water with no aeration and these treatments were considered as $\mathrm{T}_{1}, \mathrm{~T}_{2} \mathrm{~T}_{3}$ and $\mathrm{T}_{4}$, respectively. Briefly, fertilized eggs were first spread over a thin cloth supported by iron rod $(40 \mathrm{~cm} \times 30 \mathrm{~cm} \times 3$ $\mathrm{cm})$ bed and then placed in trays $(90 \mathrm{~cm} \times 50 \mathrm{~cm} \times$ $15 \mathrm{~cm})$ where experimental parameters were manipulated. In case of $\mathrm{T}_{3}$ and $\mathrm{T}_{4}$, two-third of incubated water was exchanged twice a day. Each experiment consists of three replicates with approximately 500 eggs each. All experiments were performed at room temperature $\left(28^{\circ} \mathrm{C}\right.$ $\left.30.5^{\circ} \mathrm{C}\right)$. Developmental stages were determined according to method described by Thakur (1980).

Developmental time table: Developmental stages of $C$. batrachus embryos were observed for each condition at time intervals after fertilization until they hatched out. At each stage, specimens were fixed in $10 \%$ formalin for detail studies. Observations under compound microscope (Model: XSM-10/XSM-20) on both living and preserved specimens provided information on the time intervals required for embryos to attain specific development stages. In each experiment, 
the time after fertilization for $50 \%$ of the embryos to develop to the 2-cell, 4-cell, 8-cell, morula, gastrula, yolk-plug, twisting movement, prehatching and hatching stages were estimated.

Water quality parameters: Water quality parameters such as temperature, dissolved oxygen (DO), and $\mathrm{pH}$ were recorded twice daily during morning (08:00) and evening (20:00). For consistence, mean average data (Mean \pm SD) from four replicates were presented. Temperature and DO of each tank were recorded by a mercury thermometer and DO meter (Lutron DO-5510), respectively, whereas the $\mathrm{pH}$ was recoded with the help of pH meter (Hanna ISO 9001).

Statistical analysis: Data was analyzed with Microsoft excel to evaluate the growth performance with the changes of time. ANOVA test was done at $95 \%$ significant level.

\section{RESULTS}

In the present study, spawning was noticed within $21-22 \mathrm{~h}$ after PG administration. Fertilized eggs of $C$. batrachus were demersal, adhesive, spherical and greenish in colour. Slight swelling was observed immediately after fertilization. The eggs became translucent as development progressed. Brief description and images of each embryonic developmental stage is presented in Table 1 and Fig. 1, respectively.

Comparative data under different experimental conditions on the time required for embryos to reach various developmental stages: 2-cell, 4-cell, 8-cell, morula, gastrula, yolk plug, twisting, prehatching and hatching are presented in Table 2. It was apparent that the developmental times sequentially from 2-cell to morula stages of $C$. batrachus did not differ significantly among the treatments. However, developmental stages differed significantly $(\mathrm{p}<0.05)$ from morula stages for $\mathrm{T}_{4}$ when embryos were incubated in tank where aeration and water flow were absent. In all treatments, embryos hatched successfully except for $\mathrm{T}_{4}$. In $\mathrm{T}_{4}$, embryo development stopped after yolk plug-stage.

Table 1. Brief description of embryonic development of walking catfish, Clarias batrachus.

\begin{tabular}{|c|c|c|}
\hline Stages & Description & \\
\hline Two-cell & $\begin{array}{l}\text { First cleavage, form } \\
\text { two balstomeres. }\end{array}$ & Fig. 1 a \\
\hline Four-cell & $\begin{array}{l}\text { Blostodisc divides into } \\
\text { four. }\end{array}$ & Fig. $1 \mathrm{~b}$ \\
\hline Eight-cell & $\begin{array}{l}\text { Blostodisc divides into } \\
\text { eight. }\end{array}$ & Fig. $1 \mathrm{c}$ \\
\hline Morula & $\begin{array}{l}\text { Embryos flatten and } \\
\text { resemble as cap-like, } \\
\text { blastoderm appears. }\end{array}$ & Fig. $1 \mathrm{~d}$ \\
\hline Gastrula & $\begin{array}{l}\text { Appear germinal ring } \\
\text { which is about half of } \\
\text { the embryo, } 2-4 \\
\text { somites are visible in } \\
\text { this stage. }\end{array}$ & Fig. $1 \mathrm{e}$ \\
\hline Yolk-plug & $\begin{array}{l}\text { Form embryo, head and } \\
\text { tail parts are clearly } \\
\text { visible, somites number } \\
\text { increase from } 8 \text { to } 10 .\end{array}$ & Fig. $1 \mathrm{f}$ \\
\hline Twisting & $\begin{array}{l}\text { Embryos start to move } \\
\text { slowly and somites } \\
\text { number increases from } \\
12 \text { to } 18 \text {, eyes appear } \\
\text { and heart beat starts. }\end{array}$ & Fig. $1 \mathrm{~g}$ \\
\hline $\begin{array}{l}\text { Pre- } \\
\text { hatching }\end{array}$ & $\begin{array}{l}\text { Embryos move } \\
\text { vigorously inside the } \\
\text { chorion and outer } \\
\text { chorion } \\
\text { sluggish. }\end{array}$ & \\
\hline Hatching & $\begin{array}{l}\text { Embryos come out } \\
\text { from the chorion and } \\
\text { swim freely. }\end{array}$ & Fig. $1 \mathrm{~h}$ \\
\hline
\end{tabular}

Time required to reach 2-cell, 4-cell, 8-cell, morula, gastrula, yolk-plug, twisting, pre-hatching and hatching were between 0.43 to 21.40 for $\mathrm{T}_{1}$, 0.44 to 21.56 for $\mathrm{T}_{2}, 0.50$ to 22.13 for $\mathrm{T}_{3}$ (Table 2 ). On the other hand, developmental speeds were comparable up to gastrula stage for all treatments but significantly delayed $(\mathrm{p}<0.05)$ the yolk-plug stage (10.05) for $\mathrm{T}_{4}$ from others treatments (Table 2). 

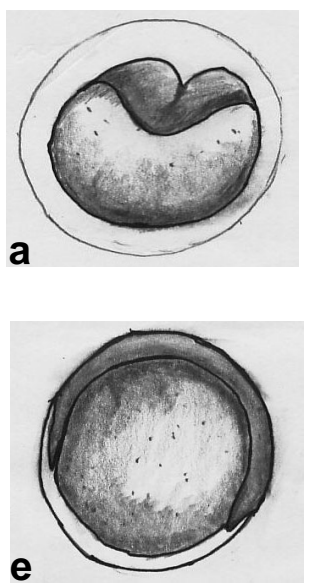
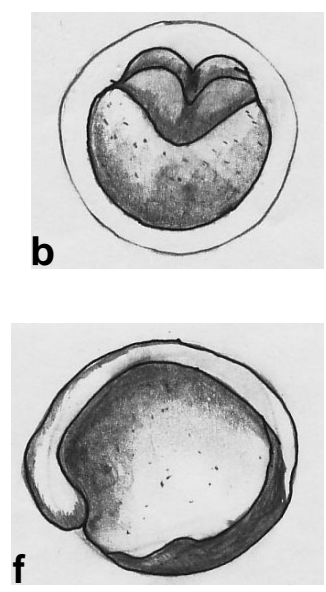
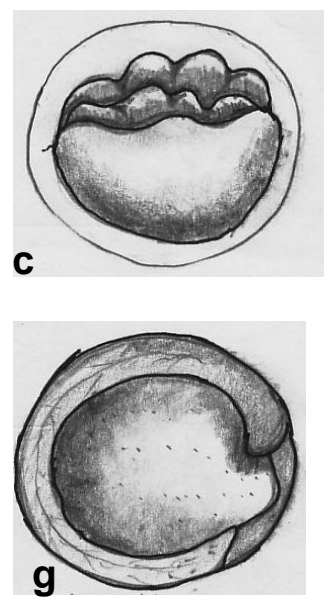
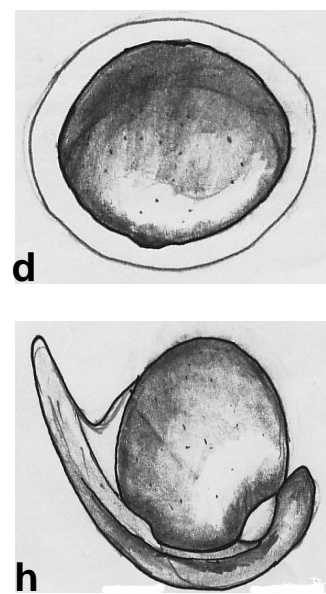

Fig. 1. Embryonic developmental stages of walking catfish, Clarias batrachus a) 2-cell, b) 4-cell, c) 8-cell, d) morula, e) Gastrula, f) yolk-plug, g) twisting, and h) hatching.

Table 2. Chronology (in hour) of embryonic development of walking catfish, Clarias batrachus at $28^{\circ} \mathrm{C}-30.5^{\circ} \mathrm{C}$. Each experiment consists of three replicates with approximately 500 embryos each. $T_{1}$ - water flow plus aeration, $T_{2}-$ water flow, $T_{3}-$ aeration, $T_{4}-$ no water flow and aeration. Each value represents Mean \pm SD. Row with different letter varies significantly $(P<0.05$, ANOVA test $)$.

\begin{tabular}{lcccc}
\hline Stages & \multicolumn{3}{c}{ Treatments } & $\mathbf{T}_{\mathbf{1}}$ \\
& 0 & $\mathbf{T}_{\mathbf{2}}$ & $\mathbf{T}_{\mathbf{3}}$ & $\mathbf{T}_{\mathbf{4}}$ \\
\hline Fertilization & $0.43 \pm 0.07^{\mathrm{a}}$ & $0.44 \pm 0.18^{\mathrm{a}}$ & $0.50 \pm 0.21^{\mathrm{a}}$ & $0.51 \pm 1.11^{\mathrm{a}}$ \\
2-cell & $0.48 \pm 0.16^{\mathrm{a}}$ & $0.47 \pm 0.22^{\mathrm{a}}$ & $0.53 \pm 0.89^{\mathrm{a}}$ & $0.57 \pm 2.23^{\mathrm{a}}$ \\
4-cell & $0.53 \pm 0.35^{\mathrm{a}}$ & $0.51 \pm 0.41^{\mathrm{a}}$ & $0.59 \pm 0.26^{\mathrm{a}}$ & $1.07 \pm 3.49^{\mathrm{a}}$ \\
8-cell & $3.52 \pm 2.16^{\mathrm{a}}$ & $3.49 \pm 3.18^{\mathrm{a}}$ & $3.52 \pm 2.01^{\mathrm{a}}$ & $4.04 \pm 3.77^{\mathrm{a}}$ \\
Morula & $6.07 \pm 1.36^{\mathrm{a}}$ & $6.10 \pm 2.78^{\mathrm{a}}$ & $6.13 \pm 2.47^{\mathrm{a}}$ & $6.18 \pm 4.41^{\mathrm{a}}$ \\
Gastrula & $8.50 \pm 1.16^{\mathrm{a}}$ & $8.51 \pm 3.02^{\mathrm{a}}$ & $8.53 \pm 2.38^{\mathrm{a}}$ & $10.05 \pm 7.98^{\mathrm{b}}$ \\
Yolk-plug & $15.04 \pm 2.48^{\mathrm{a}}$ & $15.13 \pm 2.69^{\mathrm{a}}$ & $15.11 \pm 1.89^{\mathrm{a}}$ & Ceased \\
Twisting & $20.08 \pm 2.16^{\mathrm{a}}$ & $20.19 \pm 1.16^{\mathrm{a}}$ & $20.18 \pm 3.26^{\mathrm{a}}$ & Ceased \\
Pre-hatching & $21.40 \pm 3.28^{\mathrm{a}}$ & $21.56 \pm 2.89^{\mathrm{a}}$ & $22.13 \pm 2.58^{\mathrm{a}}$ & Ceased \\
Hatching & & & & \\
\hline
\end{tabular}

Table 3. Water quality parameters under different experiments during the study period. All values represent mean \pm SD. $(n=4)$

\begin{tabular}{lcccc}
\hline Parameters & \multicolumn{4}{c}{ Treatments } \\
& $\mathbf{T}_{\mathbf{1}}$ & $\mathbf{T}_{\mathbf{2}}$ & $\mathbf{T}_{\mathbf{3}}$ & $\mathbf{T}_{\mathbf{4}}$ \\
\hline Temperature & $28 \pm$ & $28.5 \pm$ & $29.5 \pm$ & $30.5 \pm$ \\
$\left({ }^{\circ} \mathrm{C}\right)$ & 1.7 & 2.1 & 2.6 & 1.9 \\
DO $(\mathrm{mg} / \mathrm{l})$ & $6.7 \pm$ & $5.9 \pm$ & $6.3 \pm$ & $3.2 \pm$ \\
& 0.2 & 0.4 & 0.7 & 1.8 \\
$\mathrm{pH}$ & $7.6 \pm$ & $7.5 \pm$ & $7.6 \pm$ & $5.5 \pm$ \\
& 0.1 & 0.2 & 0.2 & 1.3 \\
\hline
\end{tabular}

In this study, temperature, DO and $\mathrm{pH}$ were similar for all treatments except for $\mathrm{T}_{4}$. In case of $\mathrm{T}_{4}$, DO and $\mathrm{pH}$ dropped sharply compared to other treatments (Table 3). Average temperature for $\mathrm{T}_{1}$, $\mathrm{T}_{2}, \mathrm{~T}_{3}$ and $\mathrm{T}_{4}$ was between 28 to $30.5^{\circ} \mathrm{C}$. While average DO for $T_{1}, T_{2}, T_{3}$ and $T_{4}$ were recorded as 6.7 to $3.2 \mathrm{mg} / \mathrm{l}$. The ranges of $\mathrm{pH}$ were between $7.5-7.6$ for $\mathrm{T}_{1}, \mathrm{~T}_{2}$ and $\mathrm{T}_{3}$ but decreased to 5.5 for $\mathrm{T}_{4}$. 


\section{DISCUSSION}

Embryonic and larval development of C. batrachus has been studied by several workers, including Thakur and Das (1985), Barua (1990), Thakur (1980), but little information exist regarding the effects of water flow and aeration on the early development of this species. Changes in the pattern of the entire structure of an organ or of a specific organ in relation to the environment are decisive for evaluating the developmental patterns of a species (Balon 1999). Morphological features of fertilized eggs of $C$. batrachus were similar to those reported by Thakur and Das (1985). These morphological features also resembled with $C$. gariepinus as observed by Khan and Mollah (1998).

In this study, it was observed that cell division occurred very sharply from 2-cell to 8-cell compared to other developmental stages (morula, germinal ring, yolk-plug stage, twisting movement and hatching). The 2-cell, 4-cell and 8-cell stages were observed within an hour (except for treatment, $\mathrm{T}_{4}$ where water flow and aeration were absent) after fertilization. While morula, gastrula and yolk plug stages took about 4, 6 and $9 \mathrm{~h}$, respectively. The development patterns observed in the present experiment confirms to those reported by Thakur and Das (1985) and Thakur (1980). Khan and Mollah (1998) noted the commencement of first cleavage at $45 \mathrm{~min}$ postfertilization for $C$. gariepinus which is in line with the findings of the present study. Working with another air breathing catfish (Heteropneustes fossilis), Thakur et al. (1974) reported that first cleavage occurred within 30 min after fertilization while time required for 16-cell and morula stages were about 80 and $100 \mathrm{~min}$, respectively. Similar developmental speed is reported in the same species by Puvaneswari et al. (2009) and other species also (Islam 2005). On the other hand, Banerji (1974) and Datta Munshi and Hughes
(1991) reported that in Channa punctatus, the blastula stage appeared after 2-3 h and the yolk invasion was completed at $9 \mathrm{~h}$ after fertilization. In A. testudineus, invasion of the yolk by the blastoderm was completed about $10 \mathrm{~h}$ after spawning (Datta Munshi and Hughes 1991).

Hatching of the studied species took place about $22 \mathrm{~h}$ after fertilization at the temperature ranges between $28-29.5^{\circ} \mathrm{C}$. Time requirement of hatching stage for $C$. batrachus larvae (Thakur et al. 1974) was more or less similar with the present observation. According to Khan and Mollah (1998) in case of $C$. gariepinus, hatching accomplished within $20 \mathrm{~h}$ after fertilization where the embryos were incubated at temperature between $27.5-30^{\circ} \mathrm{C}$. Kohli and Vidyarthi (1990) reported that in $H$. fossilis at a temperature of $26^{\circ} \mathrm{C}$, the incubation period of the eggs varied from 16-18 h. while longer incubation periods required (23-24 $\mathrm{h}$ at $\left.29^{\circ} \mathrm{C}\right)$ for same species reported by Puvaneswari et al. (2009). Ramanathan et al. (1985) reported in Mystus punctatus at a temperature of $28.5 \pm 1.8^{\circ} \mathrm{C}$, the incubation period of the eggs varied from 18-24 h. Banerji (1974) reported that hatching of $C$. punctatus took place $24 \mathrm{~h}$ at a temperature of $28^{\circ} \mathrm{C}$. Islam (2005) reported the same period at $26^{\circ} \mathrm{C}$ for Thai Pangas (Pangasius sutchi). In case of South American catfish (Rhamdia quelen), hatching occurred in 30 $\mathrm{h}$ after fertilization at $24^{\circ} \mathrm{C}$ (Pereira et al. 2006). Datta Munshi and Hughes (1991) reported that the incubation period in A. testudineus was around $10.5 \mathrm{~h}$ after fertilization.

Present experiment revealed that aeration and water flow have direct influence on the development of embryo. Although development speed using water flow along with aeration or water flow/aeration alone was comparable but further development ceased from twisting stage when embryos were incubated in stagnant water in the absence of water flow and aeration. 
The effective production of eggs and sperms alone would not be enough to bring about survival of species. Other factors including temperature, DO, pH, total hardness, alkalinity etc. are responsible for the development or survival of embryos after fertilization. Thus, water quality parameters must have to be optimized prior to incubation. In the study, it was observed that embryos successfully hatched when they were incubated in trays with water flow plus aeration and water flow and/or aeration. Therefore, a major concern, in terms of mass scale hatchery operation, whether continuous water flow is indispensable for incubation of C. batrachus. As we know that C. batrachus is not a riverine breeder and spawn in any haors, baors, bells, ponds, ditches etc where continuous water flow is absent. Findings of the present study confirm that only aeration in stagnant water is suitable for breeding where water quality parameters remained similar to that of $T_{1}$ (water flow plus aeration).

Maintenance of temperature, $\mathrm{pH}$ and $\mathrm{DO}$ are routine work in any hatchery operation. In all treatments except for $\mathrm{T}_{4}$, all parameters were similar and ranges were recommended for breeding. However, DO and $\mathrm{pH}$ decreased drastically for $\mathrm{T}_{4}$ (absence of water flow and aeration). Gases dissolved in the water are major factor in development, especially of eggs of oviparous fishes (Lagler et al. 1977). It may be expected that both optimum concentrations and intolerable extremes of dissolved oxygen exist and vary according to species. The generally accepted range for development lies between 4 to $12 \mathrm{mg} / \mathrm{l}$ of dissolved oxygen. $\mathrm{DO}$ in $\mathrm{T}_{4}$ was below the recommended ranges. At least two gases, carbondioxide and ammonia, in water are toxic to fishes and their embryos. Subsequent development ceased in $\mathrm{T}_{4}$ might be due to lack of sufficient oxygen supply that increased the carbon-dioxide and ammonia levels in the tank. Lowering of $\mathrm{pH}$ could be due to high production of ammonia.
Although we did not quantify the level of production of ammonia in tanks and therefore, further study could explore such predicament.

\section{CONCLUSION}

Freshwater aquaculture entrepreneurs and fish farmers in Bangladesh are fully engaged in carp species and other catfish culture. Fish farmers are lacking knowledge about breeding and early life stages that are especially sensitive and sometimes succumbed to death in mass due to unavailability of appropriate husbandry. The short embryonic period or incubation period and fast organ development of $C$. batrachus suggest that it is a suitable and potential species for small scale fish farmers and commercial culture. As pointed out earlier that species can spawn in closed water bodies and several studies suggest that this species does not require modern techniques for artificial breeding. Use of continuous water flow in hatchery is common practice in Bangladesh and marginal farmers can not afford this system due to high operation cost. Our study confirms that embryos of C. batrachus hatched successfully in trays with only aeration and embryonic development were comparable as water flow plus aeration and only water flow aided embryos. However, further studies are needed regarding larval development and quality of larvae after hatching.

\section{REFERENCES}

Balon, E.K. 1999. Alternative ways how to become a definitive phenotype or a juvenile. Environ. Biol. Fish. 56:17-38.

Banerji, S.R. 1974. Hypophysation and life history of Channa punctatus (Bloch). J. Inland Fish. Soc. India, 6:62-73.

Barua, G. 1990. Gonadal developmental and fry rearing of Clarias batrachus (Linn.). Ph.D. Thesis, Bangladesh Agriculture University, Maymensingh, Bangladesh.

ECOPRINT VOL 18, 2011 
Blaxter, J.H.S. 1974. The Early Life History of Fish. Springer-Verlag, Berlin, Germany.

Datta Munshi, J.S. and G.M. Hughes. 1991. Air Breathing Fishes of India.

Habib, M.A., S.M. Rahman, Q.Z. Hossain, M.N. Siddiqui and M.N. Islam. 2004. Developmental stages of laboratory reared Catfish, Clarias batrachus. Fourteenth Biennial National Conference. Diversity Conservation and The Zoologists. Zoological Society of Bangladesh, Department of Zoology, University of Dhaka.

Hossain, Q.Z., M.A. Hossain and S. Parween. 2006. Artificial breeding and nursery practices of Clarias batrachus (Linnaeus 1758), Scientific World. 4(4):32-37.

Islam, A. 2005. Embryonic and larval development of Thai pangas (Pangasius sutchi Fowler 1937). Develop. Growth Differ. 47:1-6.

Khan, M.M.R. and M.F.A. Mollah. 1998. Embryonic and larval development of African catfish, Clarias gariepinus (Burchell). Bangladesh J. Fish. 21(1):91-97.

Kohli, M.S.P. and S. Vidyarthi. 1990. Induced breeding embryonic and larval development in Heteropneustes fossilis (Bloch) in the agroclimatic conditions of Maharastra. $J$. Indian Fish. Assoc. 20:15-19.

Lagler, K.F., J.E. Bardach, R.R. Miller and D.R.M. Passino. 1977. Ichthyology ( $2^{\text {nd }}$ edition). John Wiley and Sons Inc.

Legendre, M. and G.G. Teugels. 1991. Development and thermal tolerance of eggs in Heterobranchus longifilis and comparision larval development of $H$. longifilis and Clarias gariepinus (Teleosei, Clariidae), Aquat. Living Resource. 4:227-240.

Marimuthu, K. and M.A. Haniffa. 2007. Embryonic and larval development of the striped snakehead Channa striatus. Taiwania 52(1):84-92.
Mollah M.F.A. and E.S.P. Tan. 1982. Effects of incubation temperature on the hatching of catfish (Clarias macrocephlus Gunther) eggs with an illustration on the larval stages. Malay. Nat. J. 36:123-131.

Pereira, C.R., L.J.G. Barcellos, L.C. Kreutz, R.M. Quevedo, F. Ritter and L.B. Silva. 2006. Embryonic and Larval Development of Jundiá (Rhamdia quelen, Quoy and Gaimard, 1824, Pisces, Teleostei), South American Catfish. Braz. J. Biol. 66(4):1057-1063.

Puvaneswari, S., K. Marimuthu, R. Karuppasamy and M.A. Haniffa. 2009. Early embryonic and larval development of Indian catfish, Heteropneustes fossilis. EurAsia J. Bio. Sci. 3:84-96.

Ramanathan, N., P. Natarajan and N. Sukumaran. 1985. Studies on the induced spawning and larval rearing of a fresh water catfish Mystus punctatus (Jerdon). Indian Acad. Sci. 94:389398.

Thakur, N.K. 1980. Notes on the embroyonic and larval development of an air breathing catfish, Clarias batrachus (Linn). J. Inland Fish. Soc. India, 12:30-43.

Thakur, N.K. and P. Das. 1985. Synopsis of Biological Data on Magur Clarias batrachus (Lianaeus). Central India Fisheries Research Institute. Barrackpore, West Bengal, India.

Thakur, N.K., R.N. Pal and H.A. Khan. 1974. Embryonic and larval development of Heteropneustes fossilis (Bloch). J. Inland Fish. Soc. India, 6:33-44.

Verreth, J., E. Torreele, E. Sparzier and A. Slurszen. 1992. The development of a functional digestive system in Clarias gariepinus (Burchell). J. of the World Aquatic Soc. 23:286-298. 